\title{
Menyusun Angkatan Sastrawan Lokal Dengan Penelitian Sejarah Sastra: Sebuah Pandangan Konseptual
}

\author{
${ }^{1}$ Moh Ridlwan, ${ }^{2}$ R. Kunjana Rahardi \\ Universitas Sanata Dharma Yogyakarta, Indonesia \\ Email: ${ }^{1}$ mohridlwan1@gmail.com, ${ }^{2}$ rahardi.kunjana@gmail.com
}

\begin{tabular}{l}
\hline Tersedia Online di \\
\hline http://www.jurnal.unublitar.ac.id/i \\
ndex.php/briliant
\end{tabular}

Sejarah Artikel

Diterima pada 4 Desember 2020

Disetujui pada 20 Februari 2021

Dipublikasikan pada 28 Februari

2021

Hal. 124-131

\begin{tabular}{l}
\hline Kata Kunci: \\
\hline $\begin{array}{l}\text { Sejarah; sastra local; konsep } \\
\text { penelitian }\end{array}$ \\
\hline
\end{tabular}

\section{DOI:}

http://dx.doi.org/10.28926/briliant. v3i4.600

\begin{abstract}
Abstrak: Artikel ini berangkat dari berbagai persoalan yang berkaitan dengan sejarah sastra lokal yang hingga saat ini minim dalam penelitian kesusastraan serta dalam forum ilmiah. Di samping itu, keberadaan sastra lokal dianggap remeh atau nomor dua setelah sastra yang berkembang secara nasional. Faktor lain adalah penyebaran karya hanya di kalangan tertentu dan keterbacaan yang sedikit sehingga dianggapnya tidak berkualitas. Kualitas karya sastra tidak ditentukan penyebaran karya atau keterbacaan. Sebab, karya sastra merupakan hasil pemikiran penulis yang merefleksikan pandanganya terhadap dunia yang dipengaruhi oleh lingkungan, sosial, budaya, dan politik. Maka, kualitas karya sastra adalah berkaitan estetika dan konteks sastra sendiri. Contoh, Chairil Anwar menjadi terkenal setelah HB. Jassin mengapresiai karyanya di tempatnya mengajar. Ada dua cara dalam penelitian sejarah sastra lokal. Pertama, klasifikasi sastrawan. Yaitu, menyusun sastrawan-sastrawan dalam kurun tertentu didasarkan pada angkatan. Kedua, karakteristik sastra. Yaitu, membahas unsur struktur sastra dengan intra struktur dan ekstra struktur.
\end{abstract}

\section{PENDAHULUAN}

Sastra Indonesia terbagi ke dalam dua jenis, yaitu sastra nasional dan sastra lokal. Menurut Herawati (2010), selama ini banyak pihak menyebut bahwa sastra yang terbit di ibu kota negera sebagai sastra nasional. Sebaliknya, sastra Indonesia yang terbit di daerah (kabupaten, kotamadya, dan provinsi) dikategorikan sebagai sastra lokal. Di samping itu, tidak jarang pendapat yang mengatakan bahwa sastra yang terbit di daerah dengan kualitas atau mutu yang bagus dan memiliki wilayah baca lintas daerah dapat disebut sebagai sastra nasional.

Adanya perbedaan antara sastra nasional dan sastra lokal membuat sastra lokal sering diabaikan, cenderung dianggap remeh, dan dianggap tidak berkualitas. Fenomena ini terjadi terhadap sastrawan-sastrawan lokal yang dianggap tidak penting jika dibandingkan sastrawan nasional yang menjadi kiblat perkembangan sastra Indonesia. Hal ini, sastrawan lokal sering terhapus oleh catatan sejarah sastra karena sejarah sastra hanya mencatat kesusastraan yang berkembang di nasional. Supriyadi (2000) menyebutkan bahwa sastrawan lokal seolah-olah merupakan sastrawan yang karyanya berkualitas rendah jika dibandingkan dengan sastrawan nasional. 
Karya sastra baik lokal maupun nasional adalah mewakili suara pengarang dengan merefleksikan pandangannya terhadap dunia melalui pola pikir yang dipengaruhi proses kehidupannya dari pendidikan, pengalaman, dan lingkungan sosio-kultural pengarang. Maka, karya-karyanya merupakan manifestasi sosiokultural kehidupan pengarang terhadap dunia. Supriyadi (2000) menggambarkan beberapa sastrawan lokal sekitar Yogyakarta yang rata-rata mengankat tema lokalitas dengan bingkai universal. Hal demikian menunjukkan bahwa sastrawan telah mewakili objek dan subjek kesastrawannya, juga objektivitas kelompokkelompok lain yang dalam pandangan Gramsci (Faruk, 2014: 62-4) disebut subjek kolektif. Menariknya, sastrawan lokal ini menjadi terkenal dan mewarnai kesusastraan nasional pada saat ini.

Menurut Muhri (2017), masalah lain dari karya satrawan lokal adalah keterbacaan. Selain karya menyebar ke kalangan khusus dan koreksi pribadi, hanya sebagian kecil yang beredar dan minim dalam kajian ilmiah. Hal ini disebabkan karena faktor lokal daerah. Padahal, kualitas karya sastra tidak selalu ditentukan oleh peredaran sebuah karya. Sebab, kualitas karya tidak ditentukan oleh jumlah pembaca. Supriyadi (2000) mencontohkan Chairil Anwar yang baru dikenal setelah meninggal. Karya-karyanya bisa diterima dengan baik setelah H.B. Jassin mengapresiasi karya tersebut dan mengajarkannya di perguruan tinggi tempatnya mengajar. Hal ini menunjukkan bahwa ada banyak faktor yang menjadi penyebab keberterimaan sebuah karya. Salah satunya dengan mengapresiasi karya sastrawan lokal, terutama dari kalangan akademisi. Hal ini akan menjadi golongan utama yang potensial meningkatkan keberterimaan sebuah karya sastra. Sebab, mereka merupakan golongan yang memiliki lembaga perguruan tinggi yang terlembaga, diakui sebagai bagian dari politik pendidikan, dan memiliki generasi yang berlanjut tiap tahunnya.

Muhri (2017) menyebutkan beberapa bidang kajian yang bisa diterapkan dalam mengapresiasi karya sastra, antara lain: kritik sastra, sosiologi sastra, psiklogi sastra, dan sejarah sastra. Dalam konteks sastra lokal, sejarah sastra akan mempelajari perkembangan kesusastraan yang berkembang di lokal, sejarah sastra mempelajari perkembangan sastra yang dihasilkan oleh suatu masyarakat atau sastrawan. Melalui penelitian sejarah sastra, seseorang akan memahami karya sastra yang pernah dihasilkan sastrawan, siapa sajakah para penulisnya, persoalan apa sajakah yang ditulis dalam sastra lokal? Seperti halnya penelitian terhadap sastrawan lokal Bangkalan generasi kedua (Muhri, 2019). Muhri membahas namanama sastrawan generasi kedua daerah Bangkalan Madura serta tema-tema apa saja yang dihasilkan sastrawan Bangkalan oleh generasi kedua. Selain Muhri, Sungkowati (2010 \& 2013) meneliti sastrawan Jawa Timur. Sungkowati membahas nama-nama sastrawa serta tempat sastrawan tinggal dan berproses.

Penelitian dalam ilmu sejarah termasuk sejarah lokal. Kuntowijoyo menyebutkan bahwa pembahasan sejarah lokal dibagi lima tema pokok, yaitu: dinamika masyarakat pedesaan, pendidikan sebagai faktor dinamisasi dan integrasi sosial, interaksi antar suku bangsa dalam masyarakat majemuk, revolusi nasional di tingkat lokal, dan biografi tokoh lokal (Muhri, 2017). Dari kelima tema pokok tersebut, tema kedua dan tema kelima yang paling sesuai untuk konteks lokal. 
Ruang lingkup sejarah sastra mencakup bidang-bidang kajian yang luas dan tersebar. Penelitian sejarah sastra melibatkan kritik sastra yang meliputi empat orientasi menurut Abrams yaitu mimetik, ekspresif, pragmatik, dan objektif. Secara teoretik, penelitian sejarah sastra dipengaruhi oleh teori-teori romantik, marxis, formalis, reseptif (Muhri. 2017). Agar penelitian sejarah sastra lokal lebih terarah, maka penelitian ini harus dikhususkan pada aspek tertentu, salah satunya difokuskan pada lingkup geografis serta dari guru ke murid atau pada sastrawan satu generasi ke generasi selanjutnya.

Selain berfokus pada geografis, mengenai klasifikasi generasi adalah suatu yang pokok dalam penelitian. Dasar klasifikasi beragam seiring dengan perkembangan paradigma penelitian yang berkembang. Dalam penelitian sejarah sastra, dasar klasifikasi yang dijadikan acuan adalah periode. Ada beberapa alasan secara objektif tentang klasifikasi jika didasarkan pembaruan kredo yang tidak bisa dilakukan, alasan mendasar karena akan tumpang tindih dengan sejarah sastra nasional. Namun, meskipun tanpa kredo, kekhasan di setiap periode selalu ada terhadap sastrawan. Terpisah dari klasifikasi atau biografi pengarang, karateristik karya sastra dalam setiap periode menjadi pembahasan utama. Karena, karakteristik sastra dalam tema, ideologi, dan konteks sosial mempunyai kekhasan setiap periodenya. Hal ini sesuai dengan pandangan Wellek \& Werren (2016: 36) bahwa sejarah sastra selain bersifat sejarah, juga sebagai kritik sastra.

Menurut Teeuw (2015: 244), setiap karya adalah manifestasi sebuah sistem yang sedikit banyak harus diuasai oleh pembaca agar karya yang dibacanya dapat diberi makna. Oleh karena itu, pembahasan sejarah sastra harus disandingkan dengan kritik sastra agar karakteristik karya sastra lebih terarah dengan memerhatikan tema, ideologi dan konteks sosial karya sastra. Karena, sastra dalam pandangan fungsional, sastra dianggap salah satu fungsi dari pekembangan masyarakat dan kebudayaan. Dengan demikian, Kleden (2004: 10) berpandangan bahwa perkembangan dalam sastra harus dilihat dalam kaitan dengan fungsi-fungsi lain dalam masyarakat dan kebudayaan.

Berdasarkan latar belakang, maka rumusan masalah penulisan ini adalah 1) bagaiman mengklasifikasikan angkatan sejarah sastra lokal ke dalam periodisasi 2) seperti apakah bentuk karakterikstik karya sastra dalam sejarah sastra lokal? Dari rumusan masalah ini dapat disimpulkan bahwa tujuan penulisan ini adalah 1) menjelaskan cara membuat klasifikasi angkatan ke dalam periodisasi sejarah sastra lokal. 2) menjelaskan bentuk-bentuk karakteristik sastra lokal dalam penelitian sejarah.

Berdasarkan dari tujuan penulisan ini, maka manfaat penulisan ini akan memberikan pemahaman terhadap pembaca untuk mengembangkan penelitian sejarah sastra lokal lebih jauh. Melalui tulisan ini, penelitian sejarah sastra tidak hanya membahas nama-nama sastrawan tempat sastrawan tianggal. Akan tetapi, penelitian sejarah sastra lokal harus membuat klasifikasi angkatan sastrawan ke dalam sejarah sastra. Selain itu, peneliti juga bisa menggabungkan antara kritik sastra dengan sejarah sastra. Hal ini mengacu pandangan Teeuw (2015:249) bahwa bahwa sejarah sastra selain bersifat sejarah, juga sebagai kritik sastra. 


\section{PEMBAHASAN}

Wellek dan Werren (2016: 3) menyebutkan bahwa sastra adalah kegiatan kreatif, sebuah karya seni. Berkaitan dalam pandangan tersebut, maka sastra bagian dari seni yang merupakan unsur kebudayaan yang berkembang dalam masyarakat. Sastra bagian dari kebudayaan adalah hasil kereativitas seseoroang yang dalam hal ini, sastrawan. Sastra telah melebur dalam pengalaman hidup manusia, baik sebagai aspek pencipta maupun dalam aspek pembaca.

Dalam wilayah studi sastra ada tiga cabang ilmu sastra, yaitu teori sastra, sejarah sastra, dan kritik sastra. Teori sastra adalah teori tentang prinsip-prinsip, kategori, asas, atau hukum yang mendasari pengkajian karya sastra. Sejarah sastra adalah ilmu yang mempelajari tentang perkembangan sastra secara kronologis dari waktu ke waktu. Kritik Sastra adalah ilmu yang mempelajari dan memberikan penilaian terhadap karya sastra berdasarkan teori sastra. Hal tersebut sesuai dengan pandangan Wellek dan Warren (2016: 36) bahwa dalam ilmu sastra, perlu disadari bahwa ketiga bidang tersebut tidak dapat dipisahkan.

Sejarah dalam KBBI (1999:981) diartikan sebagai peristiwa dan kejadian yang benar-benar terjadi pada masa lampau. Dengan pengertian dasar ini, studi sejarah merupakan studi yang mempelajari fakta-fakta peristiawa atau kejadian yang terjadi di masa lampau. Dalam sejarah, Kuntowijoyo menyebutkan bahwa peristiwa sejarah sering dicakup dalam istilah fakta sejarah. Menurut Murtini (2013), fakta sejarah memiliki dua arti. Pertama, peristiwa sejarah sebagai suatu perbuatan, aksi, tindakan, dan peristiwa. Kedua, peristiwa sejarah sebagai suatu kebenaran khusus.

Kuntowijoyo (dalam Muhri, 2017) merinci karakterisitik sejarah menjadi tiga bagian. Pertama, bersifat fakta. Kedua, bersifat singkronis, ideologis, dan unik. Ketiga, bersifat empiris. Sejarah disebut fakta bahwa peristiwa yang ditulis dalam sejarah merupakan peristiwa yang benar-benar terjadi. Sejarah bersifat singkronis diartikan sebagai peristiwa memanjang dalam suatu masa dan saling berhubungan. Sejarah disebut ideologis karena sejarah mengandung ideologi dalam mempengaruhi orang lain. Sejarah bersifat empiris karena sejarah selalu berhubungan dengan peristiwa yang dialami manusia.

Sejarah sastra merupakan ilmu interdisiplin antara ilmu sejarah dengan teori sastra dan kritik sastra. Penggabungan ini, karena sastra merupakan sistem karya yang sejajar antara kritik sastra dengan rentetan kronologis yang hanya dapat dipelajari melalui sejarah. Keterkaitan antara teori sastra, kritik sastra, dan sejarah sastra seperti yang dianalogikan oleh Wellek Werren (2016: 36) bahwa tak mungkin kita menyusun teori sastra tanpa kritik sastra atau sejarah sastra, sejarah sastra tanpa kritik sastra dan teori sastra, dan kritik sastra tanpa teori sastra dan sejarah sastra.

Menurut Yudoyono (2010: 26), sejarah sastra merupakan cabang ilmu sastra yang mempelajari pertumbuhan, dan perkembangan sejarah sastra. Misal, sejarah sastra Indonesia, sejarah sastra Jawa, dan sejarah sastra Inggris. Dengan pengertian dasar itu, tampaklah bahwa objek sejarah sastra adalah segala peristiwa yang terjadi pada rentang masa pertumbuhan dan perkembangan sastra suatu bangsa.

Sedangkan Murjianto dan Fuady (2014: ix) menyebutkan bahwa sejarah sastra adalah berbicara tentang nama-nama sastrawan-sastrawati dan parah ahli sastra, sejumlah karya sastra, utamanya yang berbentuk prosa fiksi (novel, roman, 
cerpen) dan puisi. Pendapat tersebut ada kesamaan dengan Wellek dan Werren (2016: 313) bahwa, sejarah sastra adalah sejarah sosial atau sejarah pemikiran dengan mengambil contoh karya sastra, atau impresi dari penilaian atas beberap karya yang diatur kurang lebih secara koronologis.

Dari tiga pendapat di atas dapat disimpulkan bahwa sejarah sastra adalah cabang ilmu sastra yang mempelajari pekembangan kesusastraan secara koronologis yang berkembang di suatu daerah. Misal, sejarah sastra Jawa, sejarah sastra Sunda, sejarah sastra Melayu, atau sejarah sastra lokal. Selain demikian, sejarah sastra mempelajari sejarah sosial dengan memerhatikan sastrawan, ahli sastra, dan karya sastra yang berkembang di daerah tersebut. Karena penelitian ini bersifat lokal, maka objek kajian sejarah sastra adalah mempelajari koronologis atau peristiwa kesusastraan yang berkembang di lokal dalam kurun tenterntu.

Sejarah sastra membahas sastrawan serta hasil kreatifitas dan produktivitas mereka. Sejarah sastra membahas seluk beluk kehidupan dan kelahiran sastrawan serta perkembangan-perkembangan yang terjadi dalam dunia sastra, dari karya sastra yang dihasilkan lengkap dengan perkembangannya. Atas dasar tersebut, maka objek penelitian sejarah sastra menggambarkan sastrawan-sastrawan dan karya-karya sastra yang berkambang di suatu daerah.

Karya sastra merupakan identitas terstruktur mendasar sepanjang zaman. Struktur ini bersifat dinamis dan selalu berubah berdasarkan interpretasi, kritik, dan apresiasi pembaca. Maka, tugas sejarawan sastra meletakakan kedudukan karya sastra sesuai tradisi kesusastraan. Yaitu, membuat daftar karya-karya sastra yang telah dihasilkan sastrawan dengan cara meletakkan setiap karya pada kedudukan yang tepat dalam tiap tradisi. Tugas lain adalah seperti yang dikatakan Wellek dan Werren (2016: 3016) bahwa sejarawan sastra menelusuri perkembangan karya sastra yang disusun kelompok kecil, atau lebih besar, sesuai dengan kesamaan pengarang, atau kesamaan genre, atau tipe stilistika atau tradisi lingustik.

Menurut Teeuw (2015: 245), jenis sastra sungguh-sungguh merupakan sistem bagian yang paling sesuai untuk ditelusuri perkembangan kesejarahannya. Hal ini berkaitan karya sastra merupakan bagian dari sistem kehidupan yang dipengaruhi oleh sosial, budaya serta politik yang berkembang pada masa sastrawan hidup. Karena, sastra adalah produk kebudayaan dan kebudayaan merupakan bagian dari masyarakat. Artinya, sastra, budaya, dan masyarakat saling berkaitan yang tidak terpisahkan. Hal tersebut selaras dengan pendapat Teeuw (2015:249) bahwa hubungan antara perkembangan sastra dan perkembangan masyarakat adalah hubungan timbal balik, baik sastra itu bersifat afirmatif, restoratif maupun negatif terhadap perkembangan kemasyarakatan tertentu.

\section{Klasifikasi Sejarah Sastra Lokal}

Penelitian sejarah sastra untuk menyusun sastrawan menjadi angkatan yang diistilahkan periodisasi. Oleh karena itu, peneliti harus membuat klasifikasi dalam membuat periodisasi. Klasifikasi ini adalah cara menyusun sastrawan ke dalam plot sejarah. Klasifikasi sejarah sastra adalah bagian utama dalam penelitian sejarah sastra lokal. Tanpa klasifikasi, sejarah sastra tidak mungkin disusun. Sastrawansastrawan tersebut diklasifikasi menjadi periode-periode yang diistilahkan dengan periodisasi. Dilthey mengatakan bahwa periodisasi untuk menyatukan sastrawansastrawan pada satu masa, baik secara spiritual maupun secara ideologis (Perkins, 
1992: 66). Spiritual diartikan sebagai semangat zaman yang merepresentasikan kesejarahan, sedangkan ideologi adalah yang mendasari dari ide dalam kelompok tertentu didasarkan pemikiran masa depan.

Dalam pengklasifikasian tersebut, banyak pendekatan dan metode yang bisa digunakan sebagai dasar, misalnya, pendekatan tradisional yang mengacu tokoh besar kesusastraan di masa tertentu (Teeuw, 1967:311-18). Pendekatan ini cenderung mengacu pada politik negara sebagai pusat sejarah. Pendekan tersebut tidak bisa diterapkan dalam sejarah sastra lokal karena sastrawan lokal tidak mempunyai tokoh bear.

Alternatif pendekatan dalam klasifikasi sejarah sastra lokal yang bisa digunakan adalah pendekatan pembaca, karena pendekatan ini menggunakan reseptif. Akan tetapi, permasalahan sastra lokal tidak mempunyai banyak pembaca dan akan menjadi mandul. Sealain itu, karya sastra lokal tidak banyak dibahas dalam forum keilmuan. Diskusinya pun cenderung berupa percakapan lisan. Dengan demikian, secara reseptif sastra lokal tidak bisa diklasifikasi menjadi periode-periode kesusastraan.

Pendekatan yang paling mungkin adalah pendekatan sosiologis dan struktural. Pendekatan ini tidak akan berdiri sendiri. Seperti apa yang dikatakan oleh Dilthey di atas bahwa sastra lokal tidak berdiri sendiri dan dipengaruhi oleh berbagai aspek, seperti spiritual dan ideologi. Spiritual dan idelogi terdapat aspek supranatural berupa aspek sosial. Salah satu apsek sosial adalah tempat sastrawan hidup.

Sebanding dengan pernyataan Dilthey, klasifikasi kesusastraan menurut pendapat Perkins (1992:69) ditentukan terutama oleh enam faktor yaitu: 1) tradisi, 2) minat ideologis, 3) syarat-syarat estetis penulisan sebuah sejarah sastra, 4) pernyataan sastrawan-sastrawan dan rekan sejaman tentang kesamaan minat dan penolakan, 5) persamaan yang diamati oleh sejarawan sastra antara pengarangpengarang dan/atau teks-teks, 6) kebutuhan karir profesional dan politik kekuasaan dalam institusi.

Poin-poin tersebut paling sesuai untuk klasifikasi sastra lokal. Karena, hampir sastrawan-sastrawan lokal berasal dari komunitas seni dan teater sehingga, tradisi sastrawan diturunkan melalui guru murid atau mulai dari generasi pertama sampai generasi terakhir. Minat ideologis ditunjukkan dengan pecahan-pecahan yang berpolemik lahir dari ideologi yang berbeda, tapi secara pemikiran sastrawan generasi pertama sampai generasi terakhir saling berkaitan. Adapun estetika karya sastra yang dihasilkan dalam poin 3 dan poin 4 saling berkaitan, karena sastrawan lokal dalam satu generasi dapat dipastikan dipengaruhi oleh lingkungan seperti sosio-kultural dan politik yang sama. Oleh karena itu, penyusunan angkatan sastrawan lokal dapat disusun berdasarkan tradisi dari guru ke murid, ideologi sastrawan dalam tiap generasi, biografi penulis, serta kesamaan estetika dalam setiap karya yang dihasilkan oleh sastrawan sejaman. Sedangkan poin terakhir, yaitu poin enam akan dibahas lebih dalam pada rumusan ke dua.

\section{Karakteristik Sastra}

Sejarah sastra selain berbicara tradisi, pembahasan karakteristik menjadi pembahasan yang pokok dalam penelitian sejarah sastra. Karena, penelitian sejarah 
sastra tidak cukup membahas unsur kesejarahan tanpa melibatkan makna karya sastra. Dalam konteks Indonesia, penulisan sejarah sastra dengan model penelitian ini ditulis pertama kali oleh Pradopo (2007) dengan membagi pembahasan struktur sastra ke dalam struktur estetik dan unsur ekstra estetik.

Berdasarkan deskripsi terhadap karakteristik karya setiap periode yang dilakukan, struktur estetik merupakan perwujudan dari form dan ekstra estetik merupakan perwujudan content dalam teori semiotik. Struktur estetika mendeskripsikan struktur karya sastra. Dalam prosa antara lain adalah alur, tokoh dan penokohan, sudut penceritaan (point of view), gaya bahasa, bentuk khusus kelahiran jenis sastra baru seperti roman, cerpen, novel dalam kesusastraan Indonesia. Unsur ekstra estetik mendeskripsikan makna karya sastra lebih penuh dengan pendekatan struktur dinamis yang dalam pandangan Teeuw (dalam Pradopo, 2007) adalah karangka semiotik. Karya sastra sebagai tanda terikat kepada konvensi masyarkatanya. Oleh karena itu dalam pandangan Pradopo (2001) disebutkan bahwa karya sastra tidak terlepas dari sejarah dan latar sosial budaya masyarakat yang mengahsikannya.

Latar sosial budaya dalam karya sastra berhubungan dengan perilaku masyarakat tertentu. Latar diceritakan kebiasaan hidup, adat istiadat, tradisi, pandangan hidup dan cara berpikir. Dalam proses kehidupan dengan konteks sosial yang berbeda tiap angkatan, maka karakteristik sastra dalam penelitian ini yang menjadi titik fokus pembahasan adalah tema, ideologi dan konteks sosial dalam setiap periode. Tema membahas tema-tema karya sastra dari setiap sastrawan. Ideologi menggambarkan ideologi-ideologi karya sastra yang dihasikan oleh setiap sastrawan. Konteks sosial adalah hubungan antara karya sastra dengan sosial.

Berdasarkan pembahasan di atas, penelitian sejarah sastra lokal membahas nama-nama sastrawan dengan membagi ke setiap angakatan. Selain itu, penelitian sejarah sastra lokal mengabungkan dengan kritik sastra, yaitu melihat karya sastra dari sudut pandang sktruktur karya sastra. Hal ini selaras dengan pandangan Teeuw di atas bahwa penelitian selain bersifat sejarah, juga bersifat kritik sastra.

\section{KESIMPULAN}

Artikel ini berangkat dari berbagai persoalan yang berkaitan dengan sejarah sastra lokal yang hingga saat ini minim dalam penelitian kesusastraan serta dalam forum ilmiah. Di samping itu, keberadaan sastra lokal dianggap remeh atau nomor dua setelah sastra yang berkembang secara nasional. Faktor lain adalah penyebaran karya hanya di kalangan tertentu dan keterbacaan yang sedikit sehingga dianggapnya tidak berkualitas. Kualitas karya sastra tidak ditentukan penyebaran karya atau keterbacaan. Sebab, karya sastra merupakan hasil pemikiran penulis yang merefleksikan pandanganya terhadap dunia yang dipengaruhi oleh lingkungan, sosial, budaya, dan politik. Maka, kualitas karya sastra adalah berkaitan estetika dan konteks sastra sendiri. Contoh, Chairil Anwar menjadi terkenal setelah HB. Jassin mengapresiai karyanya di tempatnya mengajar.

Ada dua cara menyusun sastrawan lokal ke dalam tiap angkatan. Pertama, klasifikasi sastrawan. Yaitu, menyusun sastrawan-sastrawan dalam kurun tertentu didasarkan pada angkatan. Angkatan diklasifikasi didasarkan pada 1) tradisi, 2) minat ideologis, 3) syarat-syarat estetis penulisan sebuah sejarah sastra, 4) pernyataan sastrawan-sastrawan dan rekan sejaman tentang kesamaan minat dan

130 BRILIANT: Jurnal Riset dan Konseptual Volume 6 Nomor 1, Februari 2021 
penolakan, 5) persamaan yang diamati oleh sejarawan sastra antara pengarang ke pengarang atau teks ke teks, 6) kebutuhan karir profesional dan politik kekuasaan dalam institusi. Kedua, karakteristik sastra. Yaitu, membahas unsur struktur sastra dengan intra struktur dan ekstra struktur.

\section{SARAN}

Artikel ini jauh dari kesempurnaan. Selain keterbatasan literasi dan informasi, juga kajian sejarah sastra lokal sangat minim dalam penelitian. Untuk menutupi kelemahan artikel ini, penulis akan terus berupaya melakukan penelitian sejarah sastra lokal demi kesempurnaan artikel-artikel atau penelitian selanjutnya. Selain itu, peneliti berharap muncul penelitian-penelitian serupa terutama yang berhubungan dengan sejarah sastra lokal. Peneliti sangat terbuka menerima saran atau masukan dari pembaca demi kesempurnaan penelitian selanjutnya.

\section{DAFTAR RUJUKAN}

Faruk (2014). Pengantar Sosiologi Sastra: dari Strukturalisme Genetik sampai Post-Modernisme (Edisi Revisi). Yogyakarta: Pustaka Pelajar.

Herawati, Y. (2010). Pemanfaatan Sastra Lokal Dalam Pengajaran Sastra. Lingua Didaktika. Lingua Didaktika, 3(2), 197-208.

Kleden, Ignas. (2004) Sastra Indonesia dalam Enam Pertanyaan: Esai-Esai dan Budaya. Jakarta: Pustaka Utama Grafiti.

Kuntowijoyo. (2003). Metodologi Sejarah. Yogyakarta: Tiara Wacana Yogya.

Muhri. (2017). Perkembangan Tema-Tema Puisi Penyair Bangkalan. Jurnal Avatisme. 20 (2): 168-80. https://doi.org/10.24257/atavisme.v20i2.305.

Muhri. (2019). Tradisi, Ketokohan, dan Karya Sastra Generasi Kedua Sastra modern Bangkalan. Jurnal Sastra Aksara, 7 (2).

Murtini. Dkk. (2019) Fakta Sejarah dalam Novel-Novel Pandir Kelana. Jurnal Sastra Indonesia 8 (3) (2019).

Perkins, D. (1992). Is Literary History Possible? Baltimore, Maryland, London: The John Hopkins University Press.

Pradopo, R. D. (2001). Puisi Pujangga Baru: Konsep Estetik, Orientasi dan Strukturnya. Humaniora Volume XIII, No. 1/2001.

Pradopo, R.D. (2007). Beberapa Teori Sastra, Metode Kritik, dan Penerapannya. Yogyakarta: Pustaka Pelajar.

Sungkowati, Yulitin. 2010. "Memetakan Komunitas Sastra Indonesia Di Jawa Timur." Atavisme $13 \quad$ (1): 100-116. https://doi.org/10.24257/atavisme.v13i1.147.100-116.

Sungkowati, Yuliatin. 2013. "Perempuan-Perempuan Pengarang Jawa Timur (Kajian Feminis)." Atavisme 16 (1): 57-69. https://doi.org/10.24257/atavisme.v16i1.81.57-69.

Supriyadi. 2000. "Sastra Lokal, Nasional, Atau Global?” XII (2).

Teeuw, A. (2015). Sastra dan Ilmu Sastra. Bandung: Pustaka Jaya.

Wellek, Rene dan Werren, Austin. (2016). Teori Kesusastraan. Jakarta: Gramadia 